
ACTA CARSOLOGICA
$32 / 2$
22
$269-276$
LJUBLJANA 2003

COBISS: 1.02

\title{
OVERVIEW OF THE KARST OCCURENCES IN NORTHERN CYPRUS
}

\author{
PREGLED KRAŠKIH POJAVOV NA SEVERNEM CIPRU \\ MEHMED NECDET ${ }^{1}$
}

${ }^{1}$ Mehmet NECDET, Geology and Mines Department, Turkish Republic of Northern Cyprus

Prejeto / received: 2. 9. 2003 


\section{Abstract}

UDC: $551.44(564.3)$

\section{Mehmet Necdet: Overview of the karst occurences in northern Cyprus}

Cyprus is at the easternmost part of the Mediterranean and is in the intersected zone bezween Eurasia, Africa and Arabic Plates. Karstification occurs as travertines or caves in Northern Cyprus in formation of different ages. Those formations are the dolomitic limestones of Kyrenia (Girne) Range of Jurassic - Upper Cretaceous; Gypsum Deposits of Messinian ages. Travertine terraces (Quaternary) are seen as characteristic at the northern edge of the Kyrenia Range. Secondary limestones of Holocene age were deposited on the older sediments and seen with some sort of karst features over the island. Karstic occurrences are seen as different size of open or sealed caves and the sinkholes in those formations mentioned above.

Key words: karst, Holocene karst, travertine, Kyrenia, Northern Cyprus.

\section{Izvleček}

UDK: 551.44(564.3)

\section{Mehmet Necdet: Pregled kraških pojavov na severnem Cipru}

Ciper je v skrajnem vzhodnem delu Sredozemlja, na stičišču evrazijske, afriške in arabske plošče. Kraški pojavi severnega Cipra so predvsem lehnjaki in jame v različno starih kamninah. To so dolomitni apnenci pogorja Kyrenia (Girne) jurske-zgornjekredne starosti in usedline anhidrita mesinijske starosti. Značilnost severnega roba Kyrenije so kvartarne lehnjakove terase. Po vsem otoku so kraški pojavi v sekundarnih apnencih holocenske starosti, odlo•nih na starejše usedline. Kraški pojavi v teh kamninah so različno veliki odprti ali zamašeni jamski vhodi in vrtače oziroma grezi.

Ključne besede: kras, holocenski kras, lehnjak, Kyrenia, severni Ciper. 


\section{KARST FEATURES}

Cyprus is the third biggest island in the Mediterranean Sea and located in the semi-arid climate belt. The karst features in Northern Cyprus are seen in the landforms which are given below (Fig. 1):

- Kyrenia Range Limestones

- Tufa Terraces

- Gypsum

The main limestones of the Kyrenia Range are; Dhikomo (Dikmen) Marble [thinly bedded limestone is the oldest limestone group of Triassic age]; Sykhari (Kaynakköy) Dolomite [Jurassic age highly tectonized, intensely brecciated dark grey colour formation]; Hilarion Formation [Most of this limestone has been recrystallised to marble or semi-marble; Also in some places it is partly dolomitic and may then be easily mistaken for Kaynakköy ( Sykhari) dolomite. The age of this formation is Jurassic] and Kantara Limestones [Permian age massif limestone which occurs as olistoliths in the eastern part of the Range] ( Dreghorn, 1978; Baroz,1979).

The vegetation cover on the two flanks shows a marked contrast, the northern slopes being well clothed with pine and cypress forests whilst the southern slopes bear garrigue and maquis scrub down to the semi-arid plains of the Mesaoria.The emplacement of the main limestones was due to gravity sliding from the Taurids (Dreghorn,1978).

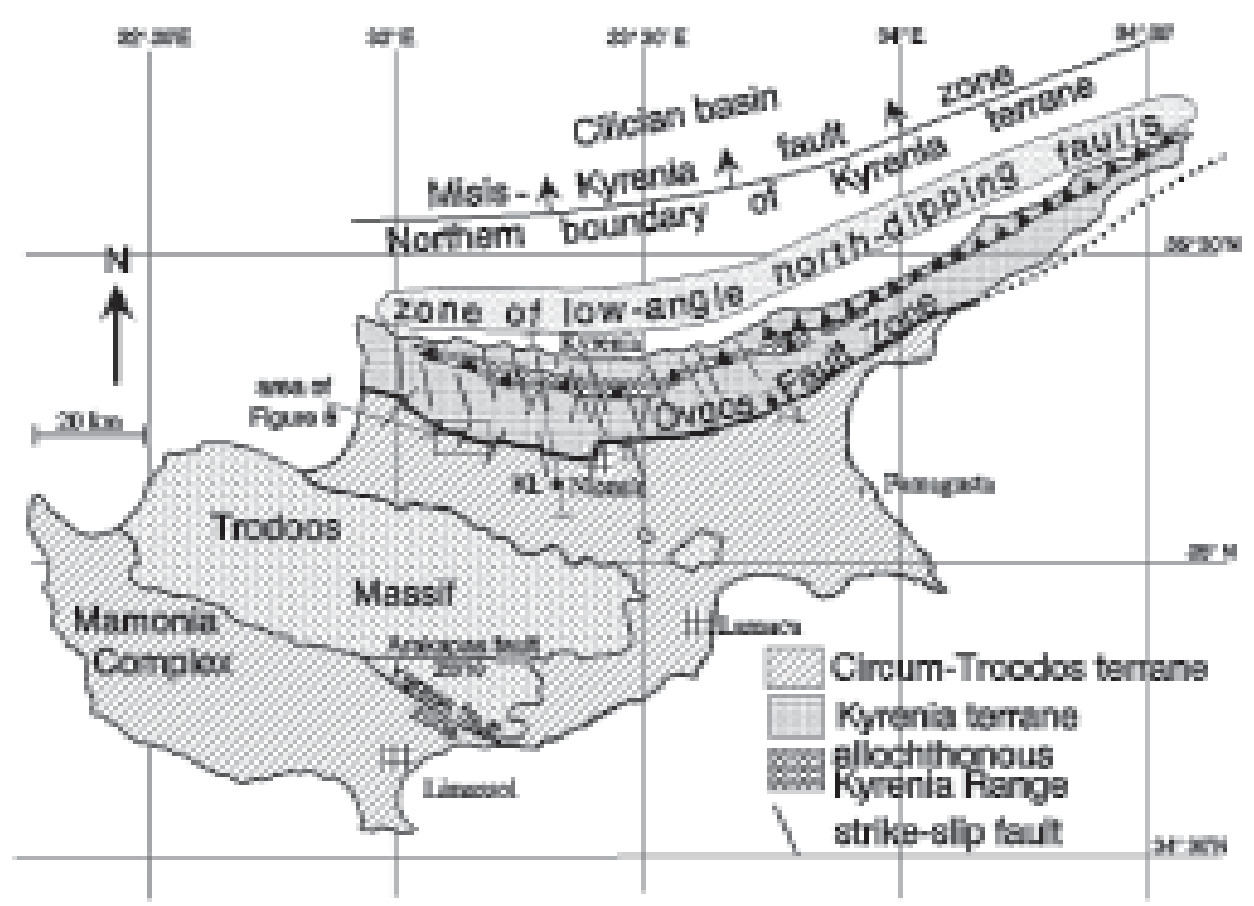

Fig. 1 


\section{KARSTIC FEATURES IN KYRENIA RANGE}

\section{Intermontane Plains}

Intermontane Plains in Kyrenia Range are orginated as a structural feature due to the tectonic uplift of the island.

The intermontane plains are evolved into flat-floored depressions through to the differential erosion of soft Lapta Rocks enclosed between thrust masses of Hard Mountain Limestones.

\section{Polje}

Hilarion Limestone bears a few poljes which occur as elongated depression intermontane valleys above $400 \mathrm{~m}$ altitude. The most elongated polje is an enclosed high plain on the southern side of Pentadaktylos (Beşparmak) Crest. The extent from east to west is $1.9 \mathrm{~km}$ and the average width is $300 \mathrm{~m}$.

\section{Dolinas}

In the Hilarion Limestone group, a series of small rhomboidal plains each less then $500 \mathrm{~m}$ width; small and fairly flat oval plain about the size of a football field. A few of them have no exit channel. These dolinas are all interconnected and may be the remains of an ancient transverse drainage system. The floors of the poljes and dolinas bear terra rossa soils, thinly laminated silts and secondary limestones.

The poljes and dolinas are clues of the "tectonic windows". The surface erosion has almost ceased but the solution processes still continue (Dreghorn, 1978).

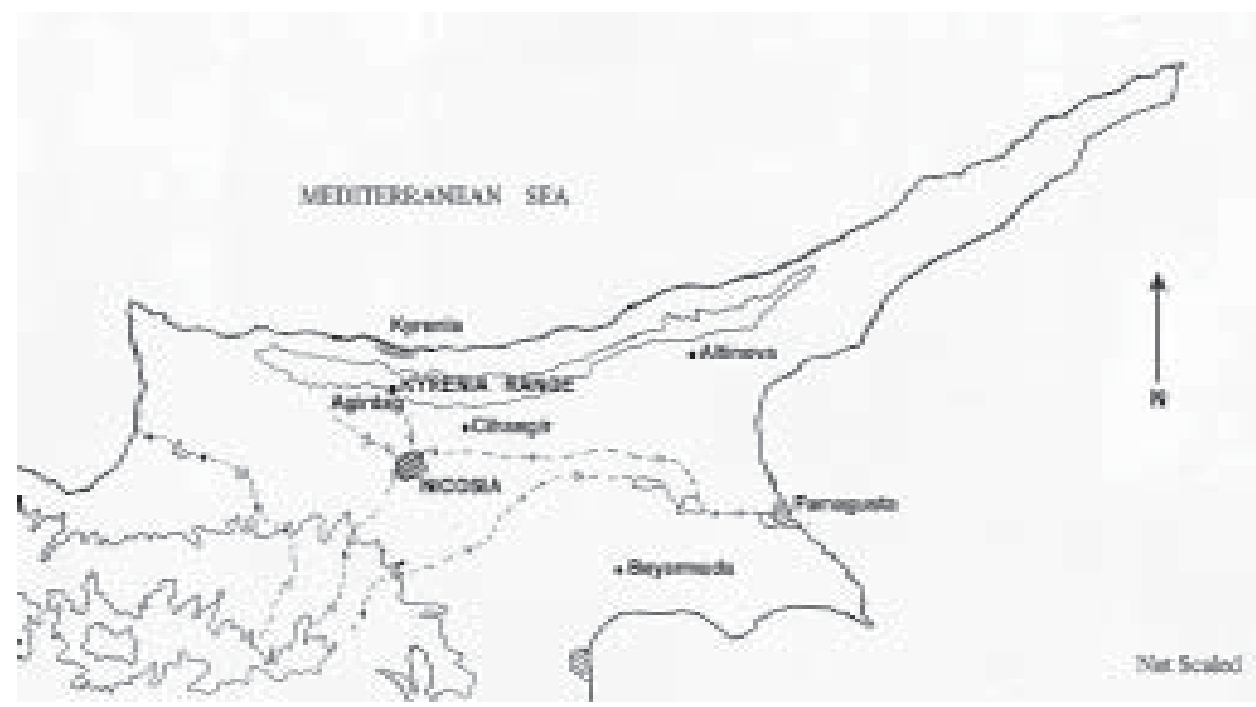

Fig. 2 


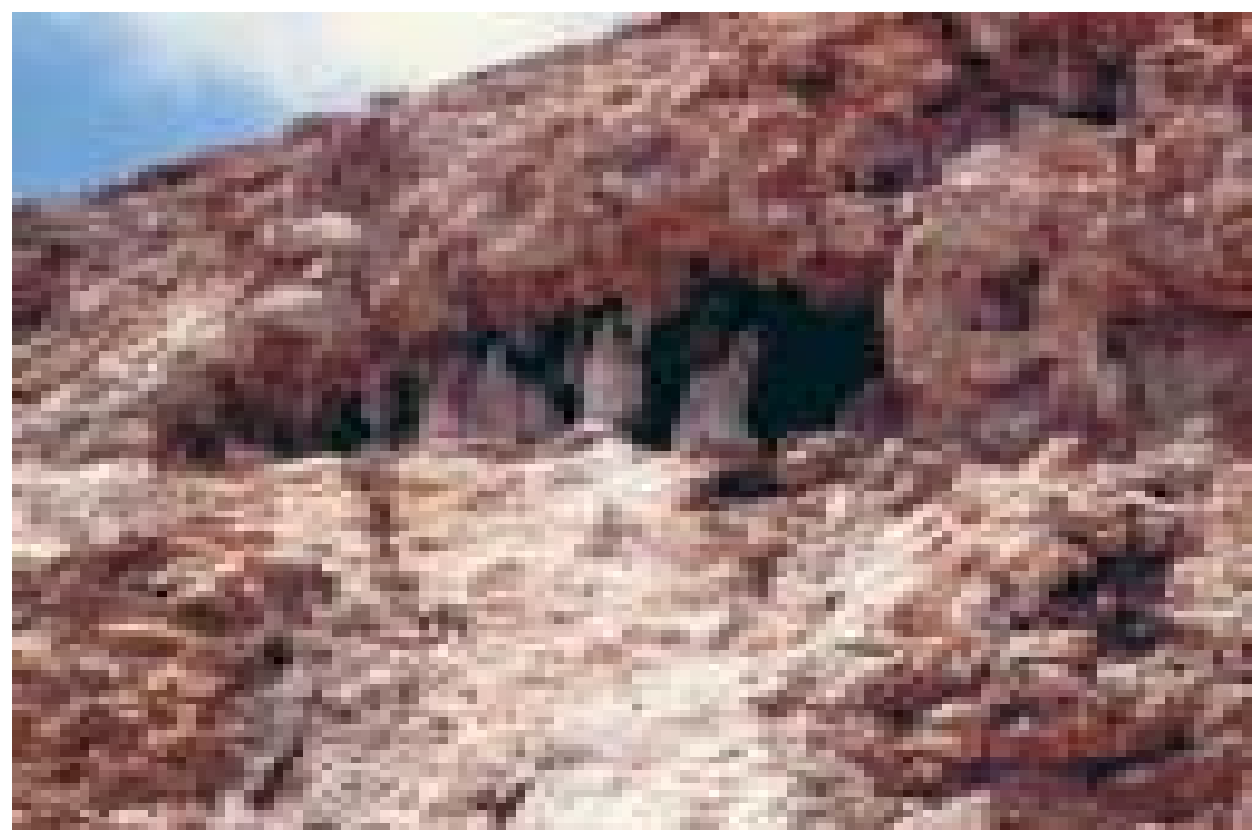

Photo 1: Stalactites and stalagmites in travertine at Ciklos site northern flank of the Kyrenia Range.

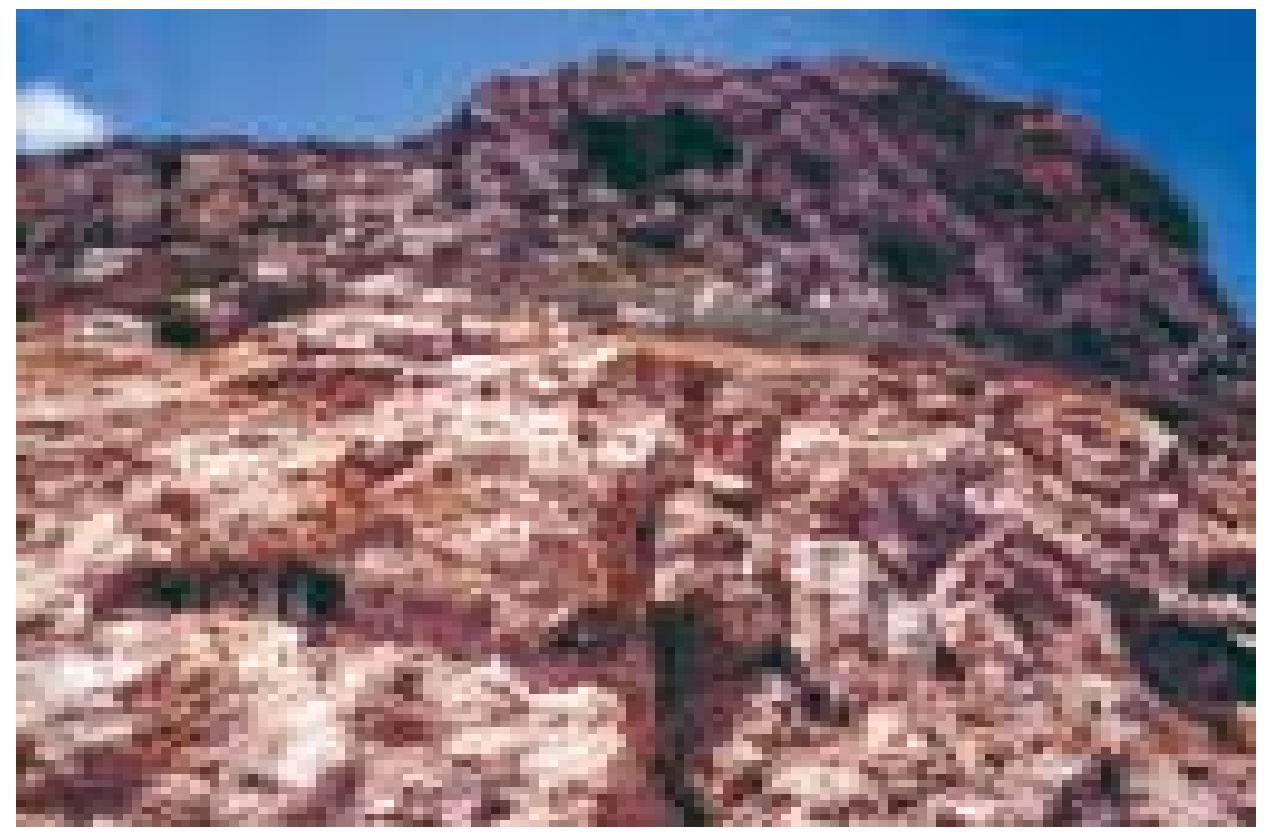

Photo 2: A general view from the travertine at Ciklos site. 


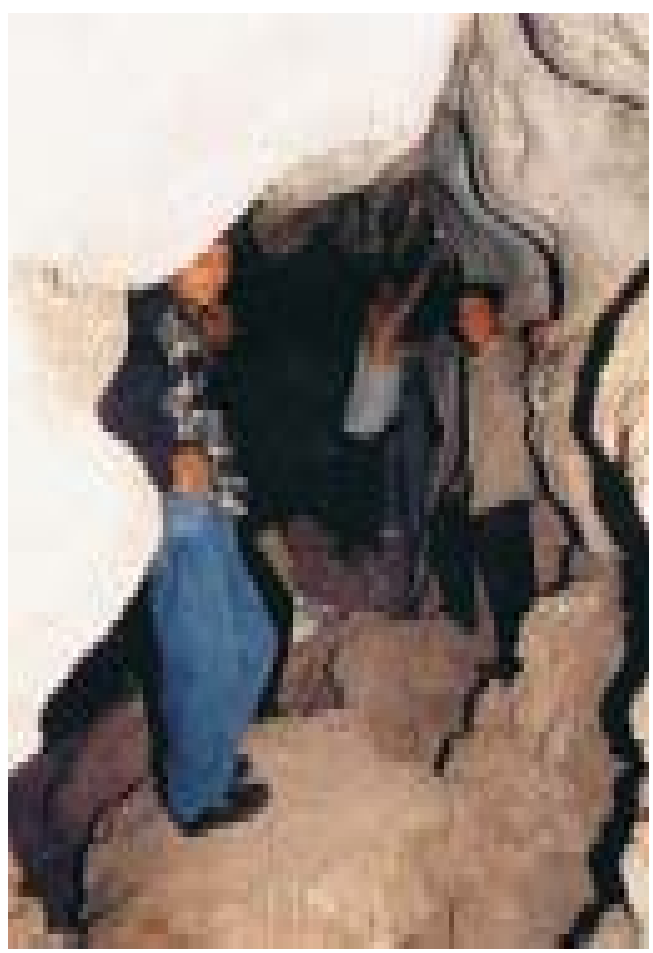

Photo 3: An inside view from the Incirli cave.

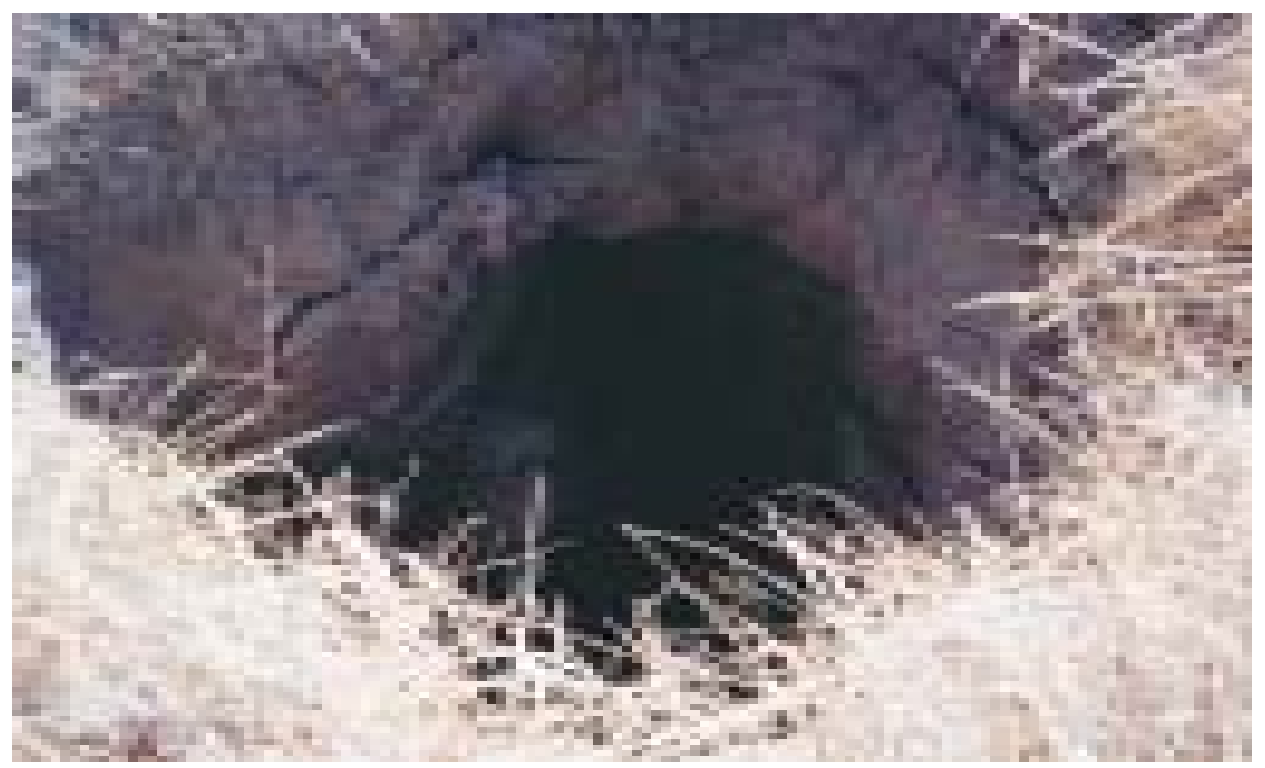

Photo 4: A view from the sinkhole northeast of Cihangir village. 


\section{Tufa Terraces}

Tufa terraces occur in the western and central portions on the northern flanks of the Range.Their origin is the evaporation of the high carbonate content spring water which were active during the pluvial periods of the Pleistocene. They must have been formed during periods of high rainfall.(Photo 1 and photo 2 ).

The thickest one is about $30 \mathrm{~m}$, structureless with hollows and caves with petrified vegetation.

\section{Caves}

There are no large underground systems and so far as is known none has great depth. They occur at the contact of the Mountain Limestones with the beds of the Lapta chalks and younger units.They can be classed as tectonic caves with shallow depth and usually associated with fossil springs. The groundwater movement is the minor aspect for the cave occurence.

All the known caves are fossil ones, having no present flow of water, because of their height above the existing water level.

\section{GYPSUM KARST}

There is $150 \mathrm{~km}$ long belt occuring as separate bodies of gypsum deposits in Northern Cyprus.The age of these gypsum deposits are late Messinian. Selenitic and fine grained laminated gypsum facies are seen as dominant.

The best known gypsum cave is in the eastern extension of North Cyprus. "Incirli Mađara", west of Altinova village, occurs on the southern limb of a syncline and is entered from an entrance at the east. The axis of this cave is almost east - west.The length is almost $250 \mathrm{~m}$ with $5-10 \mathrm{~m}$ width and $4-7 \mathrm{~m}$ height. (Photo 3 ).

\section{Sinkhole Problems in Gypsum Deposits}

The dissolution and tectonic processes are the main factors affecting the sinkholes in the burried gypsum deposits. These sinkholes are seen in the rural areas almost $30 \mathrm{~km}$ north-east (between Minareliköy and Cihangir villages; Photo 4) and $20 \mathrm{~km}$ southeast of Nicosia (Akincilar village). The sinkhole at the most eastern part of the island occurs at an active fault south-east of Beyarmudu village.

\section{CONCLUSION}

Paleokarst started its development during the presumed pluvial periods of the Late Pleistocene and then continued at a much slower rate under the more recent semi- arid conditions.

The existing karst formations are well developed on the Mesozoic Limestones of Kyrenia Range, due to solution through in the fissures directly related to tectonic stress.

The repeated tectonic movements have prevented the development of large subsurface drainage systems in the Kyrenia Range limestones. The predominance of almost vertical structures have been noted as another key element.

Sinkholes occur in the rural areas due to pumping from the gypsum aquifers for irrigation. This process is accelerating the dissolution of the gypsiferous lithology between extraction and 
replenishment periods as well. Another issue is the surface water which flows along the fault system, resulting in dissolution of gypsum and carbonate at depth, and subsequent surface collapse after intense rainfall like the Beyarmudu sinkhole phenomena.

\section{REFERENCES}

Baroz, F., 1979. Etude géologique dans le pentadaktilos et la Mesaoria. 365 p, Ph.D Thesis, University of Nancy.

Dreghorn, W., 1978. Landforms in the Girne Range, Northern Cyprus, MTA Enstitusu Yayinlari, No: 172, 220 s., Ankara. 